\title{
THE EQUITY OF THE FINANCIAL ALLOCATIONS IN THE EUROPEAN UNION
}

\author{
Teaching Assistant PhD Student Ana-Maria Marinoiu, Academy of Economic Studies of Bucharest, e-mail: \\ anamarinoiu@yahoo.com \\ PhD Student Doina Crişan-Hăbeanu, Academy of Economic Studies of Bucharest, e-mail: \\ doina.crsan@ase.ro
}

\begin{abstract}
In order to increase the degree of absorption of the post adherence funds it is recomanded to use some general methods that must be implemented at the level of the decisional structure in our country.

Among these one must mention: the clear definition of the list of eligible expenditures and the general rules of eligibility, the reduction of bureaucracy and the numerous formal aspects, the quick promotion of eligibility guides for all the operational programs, the enhancement of the income level among the employees in the public administration sector for the purpose of balancing the cost and advantages related to the jobs involved in the management of structural funds and the loyalization of the employees, the enhancement of the degree of responsability of the local authorities in order to enhance the investments intended for the economical relaunching on a local area and the identification of viable posibilities for co-financing both for the public sector as well as for the privat one.
\end{abstract}

Keywords: financial alocation, absorption degree, structural funds, The European Union

JEL Codes: H53, E01, F42

\section{Romania's contribution to the community budget as a member state}

From the perspective of its quality as Member State, beginning with the year 2007, Romania will have to ensure the payment of its contribution for the financing of the budget of the Union as part of system of internal resources of the community budget. The internal resources of the European Community can be defined as being allocated revenues from and for the Community with the purpose of financement of the budget of the European Union.

As any budget, the European Union's budget is meant to be very clearly used on chapters of expenses and incomes.

According to article 269 of the Treaty of The European Union the community budget is financed totally from internal sources represented by:

Traditional internal resources, which mainly consist in revenues originated from custom duties applied on imported products or product coming from non- European Union countries, as well as agricultural contributions and taxes regarding sugar (aproximatively $15 \%$ of the community budget. The custom duties and agricultural taxes arise from the application of the Communities customs legislation and the Common Agricultural Policy regarding the imports from third party countries. The taxes regarding sugar are applied to the producers in the sugar sector and are used to cover the Community's expenses in this sector.

The revenues from the Value Added Tax (VAT), calculated on the ground of a redemption quota applied to the revenues from the VAT of all member states." The Internal resource VAT " is not a percentage from the VAT revenues on the national level but a percentage applied to the total value of the activities liable to VAT, according to the sixth Directive and the Regulation number 1553/89. The total of these values represents also "The Basis of the Resource VAT". The basis of 
evaluation of the VAT of a member state cannot exceed $50 \%$ of the GNP of that member state. In the situation of applying more VAT quotas, one can calculate a medium quota to determine "The basis of taxation"; in exception cases, it can be quantified the influences of these exceptions on the "the basis of taxation" and, annulling them, the basis can be readapted so that it leads to a "unitary basis of taxation for the resource VAT". The rate applied to the basis VAT was established at $0.5 \%$ through the Council's Decision 2000/597/EC.

Revenues from the Gross National Income (GNI), the resource GNI derives from the application of a uniform rate $(0.73 \%)$ over the GNI of every member state. Initially, the calculus of the national contributions to the budget of the European Union was done by reporting it to the Gross Domestic Product, but due to the fact that, in the case of very open economies, the Gross Domestic Product (GDP) and the GNI can be considerably different, it has been established as basis for calculation the GNI.

A feature of the "System of internal resources" is the correction of Great Britain which represents a mechanism of correction that reduces the budgetary disequilibrium of Great Britain throughout a reduction of payments linked to the VAT and GNI. The cost of this correction is assumed by the other member states regarding their part in the GNI of the Community. At any rate the financial contribution of Austria, Germany, Holland and Sweden is restrictioned to a quarter of their usual contribution.

The internal resources of the European Union are established, cashed, payed and controlled according to the regulations of the" Sistem of INTERNAL resources "effective presently, respectively the Decision of the Council number 597/2000/CE, Euratom and its two Implementation Regulations: the Regulation of the Council (CE, Euratom) number 1150/2000 and the Regulation of the Council (CE, Euratom) nr.1553/89.

The internal resources based on the VAT and the GNI are payed to the Committee every month representing $1 / 12$ of the sum comprised in the approved budget or the approved rectified budget. Due to the special payments in agriculture, The Committee can demand the member states to pay these resources (VAT, GNI) a month or two in advance in the first trimester of the year.

The member states are, among others, responsible for: the collection and providence of the internal traditional resources for The Committee, the calculus of the bases of VAT and Gross National Product (GNP)/GNI the payment of resources coming from VAT and GNP/GNI.

The connection between the Commity and the Member states is institutionalized through the Consultative Committee of internal resources and the Committee of GNI. These committees are formed by representatives of the member states and the committee.

According to the Treaty of Adherence to the European Union, beginning with the date of adherence, Romania will pay the community budget 42300000 euro, a sum corresponding to the countries' contribution to the capital transferred into the account of the subscribed capital. This contribution will be payed in 8 equal installments at the following dates: $31.05 .2007,31.05 .2008$, 31.05.2009, 30.11.2009, 31.05.2010, 30.11.2010, 31.05.2011 and 30.11.2011.

Our country will contribute also to the sums that will complete the reserves, consisting in the balance between profit and loss, established at the end of the month that proceeds the adhere cement, through sums according to the following percentage of the reserves and stocks: $0,517 \%$. The payments will be made in cash in euro, except some derogations accepted unanimously by the board of governors.

Romania will pay to the Fund of Research for Coal and Steel 29880000 euro in 4 installments starting in 2009. The payment will be made on the first working day of every year as follows: 
Romania's contribution to the Fund for Research for Coal and Steel

Table no. 1.

\begin{tabular}{|l|l|}
\hline \multicolumn{1}{|c|}{ Year } & $\begin{array}{c}\text { Romania's contribution to the Fund for } \\
\text { Research for Coal and Steel }\end{array}$ \\
\hline 2009 & 4482000 euro $(15 \%)$ \\
\hline 2010 & 5976000 euro $(20 \%)$ \\
\hline 2011 & 8964000 euro $(30 \%)$ \\
\hline 2012 & 10458000 euro $(35 \%)$ \\
\hline
\end{tabular}

Source: The Ministry of Public Finance, www.fonduri-ue.ro

\section{European Funds-The financial allocation Romania 2007-2013}

The Structural and Cohesion Funds (SCF) or Structural Instruments are financial instruments with which the European Union acts to eliminate the economic and social disparities between areas, with the purpose of achieving economic and social cohesion and they comprise: Structural Funds ( The European Fund for Regional Development (EFRD) and the European Social Fund (ESF)) and the Cohesion Fund.

The total sum allocated to the Structural and Cohesion Funds 2007-2013 is: 19.213,04 mil. Euro out of which:

- The value allocated to the Cohesion Fund: 2007-2013- 6.552,43 mil. euro

- The value allocated to the European Fund for Regional Development 2007-2013- 8.976,47 mil. euro

- The value allocated for the European Social Fund 2007-2013- 3.684,14 mil. Euro

Tabel no. 2.

Table regarding the financial allocation 2007-2013 Structural and Cohesion Funds

\begin{tabular}{|l|l|l|l|l|l|l|l|l|}
\hline Fund & 2007 & 2008 & 2009 & 2010 & 2011 & 2012 & 2013 & TOTAL \\
\hline EFRD & 596,99 & 857,60 & $1.161,41$ & $1.416,92$ & $1.528,80$ & $1.628,04$ & $1.786,71$ & $8.976,47$ \\
\hline CF & 444,94 & 638,42 & 858,51 & $1.030,21$ & $1.109,47$ & $1.192,58$ & $1.278,3$ & $6.552,43$ \\
\hline ESF & 233,14 & 358,29 & 493,43 & 580,09 & 625,46 & 691,15 & 702,58 & $3.684,14$ \\
\hline TOTAL & $1.275,07$ & $1.854,31$ & $2.513,35$ & $3.027,22$ & $3.263,73$ & $3.511,77$ & $3.769,59$ & $19.213,04$ \\
\hline
\end{tabular}

Source: MFP www.fonduri-ue.ro

The allocation of CSNR in the Objective "Convergence" and the Cohesion Fund requires a national co-financing estimated at $5,53 \mathrm{mld}$ euro, comprised of both public sources $(77 \%$ out of the total of the co-financing) as well as private sources(23\%).

The European Fund for Agriculture and Rural Development (EFARD) and the European Fund of Pisciculture (EFP).

Romania benefits from special funds dedicated to agriculture and fishing: The European Fund for Agriculture and Rural Development (EFARD) and the European Fund of Pisciculture (EFP)

Table no. 3 .

Table regarding the financial allocation 2007-2013 EFARD and EFP (mil. euro)

\begin{tabular}{|l|l|l|l|l|l|l|l|l|}
\hline Fund & 2007 & 2008 & 2009 & 2010 & 2011 & 2012 & 2013 & TOTAL \\
\hline EFARD & 741,66 & $1.023,08$ & $1.319,26$ & $1.236,16$ & $1.234,24$ & $1.235,54$ & $1.232,56$ & $8.022,5$ \\
\hline EFP & 15,13 & 22,16 & 30,16 & 36,39 & 39,26 & 42,26 & 45,36 & 230,72 \\
\hline
\end{tabular}


Source: MFP $\underline{\text { www.fonduri-ue.ro }}$

\section{The necessity to ensure a high level of absorption of the Structural and Cohesion Funds}

As part of the European Union, the policy for regional development represents the main instrument through which it is attempted to achieve the objective of economic and social cohesion. Considering the importance that the process of integration in the European Union and the diminishing of the social and economic differences represents to Romania, it is considered that it is essential that the policy of regional development becomes a priority for the government.

As far as the policy of regional development and the system of institutional organization is concerned, the following fact have been established:

$>$ the degree of absorption of fund by Romania is very low (we are speaking mainly about the degree of absorption of the pre-adhering funds) firstly because of the reduced administrative capacity, including here also the reduced degree of employment for specialized staff.

$>$ there has been noticed a worsening of the problems with which the 8 regions of development are faced. The majority of the programs and the implemented projects have had no semnificative impact in settling the major problems which every region is facing, moreover they have encouraged the increase in differences between regions;

$>$ the policy of regional development has represented a secondary goal for the Ministry of European Integration, the main objective being the finalizing of the adheration negotiations and the harmonization of Romanian legislation with the communitary acquis.

$>$ the proper integration is realized at a local/ regional level towards the center and is linked mainly to the existing abilities and resources at a regional level. The policy for regional development and the policy for structural instruments does not admit a "forced" integration, either imposed by unfavorable circumstances, consequence of administrative disabilities or hastily measures.

So, considering the principles of efficiency and investment utility, there can be considered some directions of action on the following components of the absorption process of the SCF:

$>$ From the point of view of the section component, it has not been considered the importance of concentrated action of the public policies especially of those in the economic sector. Many times these have been applied antagonistically and the promotion of one has caused the neglect of another.

Therefore, based on the principles and the Government Program we have to focus on:

- the creation of a structure at the level of the Prime Minister which will ensure the correlation of the public policies objectives and operational programs;

- insuring at the Prime Minister level the decisional framework needed for the implementation of the competitive policies at the level of the whole territory, throughout the valorizing of the comparative and competitive advantages existing at the level of each region;

- The orientation of the business environment through the presentation of the investment opportunities, on the basis of the regional development criteria;

$>$ From the point of view of the administrative component, there were many actions just to point out the accomplishment of an acquis demand, without considering the necessity to flexify the administrative-institutional sector. So, we have to consider the following course of action on this component:

- $\quad$ insuring the infrastructure and necessary logistics in the public administration;

- creating an informational loop, which will make the activity of the depending and coordination entities more efficient, through the accurate choice of information, access to the data base, to ensure that there is a view of the whole frame, to prioritize the decision making process; 
- continuous preparation of personnel, for example, through the elaboration of an annual programme for the professional training of the personnel involved in the management of the Structural Funds;

- the strengthening of the inter-institution collaboration relations and the flexibility of the reference mechanisms for reporting;

- the ruling out of short circuits and the jamming on the relation $\mathrm{OI} \leftrightarrow \mathrm{AM} \leftrightarrow \mathrm{AP}$;

- focusing on the role of local and regional structures involved and acknowledging the problems faced by them;

- correction and rulling out legislative interpretations that can cause blocking in implementing programmes, especially on stages of implementation and control;

$>$ From the point of view of the financial component, there have been developed plans, strategies and documents regarding the degree of absorption of communitary funds without considering that this depends mostly on the internal financial resources. To facilitate the absorption of funds one has to consider:

1. achieving a partnership relation between beneficiars and banking and credit institutions to facilitate the procurance of co-financing;

2. grant support to the counties which have difficulties in assuring the co-financing;

3. the analysis of opportunities in order to create special funds (IFI+FN) at the disposition of the state to ensure co-financing for national objectives;

From the point of view of the evaluation and control component, the course of action in this sense have been focused exclusively based on bureaucratic and documentary control, statement cannot help in clearing the situation. In this sense we propose:

- accomplishing a real project based portfolio, beginning with the priorities established in POS;

- the selection of a number of relevant pointers to evaluate the social-economic impact on projects;

- focusing the control actions on the prevention components, risk analysis and the final stage of the investment;

\section{The factors that influence the capability of absorption of European funds}

The absorption capability of structural and cohesion funds in Romania depends on four factors that are essential for the administration process. These factors regard both petitioners as well as public institutions involved in the administration of European funds. The four essential factors involved in accessing the funds are: the beneficiaries' ability to prepare and implement projects, the market's ability to produce goods, services and projects that are to be purchased as part of projects , the ability to co-finance projects by the beneficiaries. ${ }^{1}$

In the "Monitorisation Report for Romania" from 25th of October 2005, the European Committee has presented the situation of the administrative capacity for the country in the area of regional policy and also the coordination policy for Structural Instruments ( Chapter 21) achieving the following main idea: "There are serious concerns regarding the administrative ability of the institutional structures and also in the area of financial and control management. Immediate action is necessary to strengthen the administrative ability at the level of all the structures involved on a national, regional and local level...........]"

Although there have been almost 11 months since the integration to the European Union (November 2007) "WHY HAVE WE MANAGED TO ABSORB “0” STRUCTURAL FUNDS?" is the question most often asked by politicians lately.

To understand the answer to this viciously formulated question one must know precisely the mechanism for granting European funds. In reality, for the moment, there is no possibility to 
quantify the degree of absorption of the post-adherence funds due to various reasons like:

$>$ These funds, although they were intended for Romania, can only be assigned after following some precise procedures established by the Committee. It is not enough just signing the operational programmes on sectors to obtain money from the Romanian treasury. It has to be considered that these documents were signed and published officially only at the end of the month June 2007. From that moment on the programmes could have been launched effectively to receive projects. Even if a programme would have been started at the 1st of August 2007, following the necessary stages, it is hard to believe that it would have registered already a degree of absorption of funds. The reason for this statement is represented by the fact that one has to follow all the stages until the moment of concrete absorption of the money as follows: in a first stage after the signing of the POS the Management Authorities will launch programmes and elaborate The Petitioner's Guides. Based on these possible beneficiaries the demand is filled in and the projects are applied. After they reach the resort authorities the projects are evaluated and if they meet the case they are selected and the next stage is the signing of the contracts and the start of the activity. From this moment on the beneficiary can register a series of expenses that will later be certified and cleared if everything is in order. Only after this moment one can speak of managing a financial on flow from the European Union. Totally these procedures last for about three-four months.

$>$ The Romanian authorities are held responsible for a delay in publishing the documents and the actual launch of the auctions after the approval of the main operational programmes during June.

$>$ A very important feature when an answer to this question is sought is linked to the fact that the "success" for funds intended for the year 2007 can be quantified only at the end of 2010 according to the rules of these programmes $(n+2, n+3)$. Only them can we say for certain what amount of money has been spent or lost.

\section{Aspects that can influence the degree of absorption of the communitary funds}

The experience accumulated in the case of pre-adheration funds (PHARE, ISPA and SAPARD).One can mention the PHARE programme, which is very well known and has absorbed very important funds. Also, the SAPARD programme is qualified as a very successful programme and has a great receptivity among farmers and in the rural environment, in general. As an indicator of the impact this programme has one can mention the intention of the Romanian Government to start a similar local programme. However, the majority of problems are noticed at the ISPA programme, due to on the one hand, the technical aspects regarding infrastructure projects( for the road projects, for example, there has been a defectuous technical training, although there were many projects badly written), At the same time, it is mentioned that the ISPA projects were of a much bigger width than the programmes PHARE. Practically, a part of these problems are assigned to the main beneficiaries, although it is mentioned that one can also speak of problems generated by the administrative capacity of the Transport Ministry and its main agencies, because these structures have been in a continuous modernization from the moment the financing through European funds began ( modernization regarding personnel training, its capacity to draw up the documentation and to certify, monitor financially evaluate the stages of implementation).

As a result of the administration of pre-adherence funds one can classify two main revenue categories:

- direct revenues, the result of different investments realized thorough projects( infrastructure, business development), at which the success index would be an absorption indicator of each of these funds;

-indirect revenues which, in view of the imminent administration of structural funds, are of a significantly larger impact. One must mention in this context the development of the institutional infrastructure, including the human resources infrastructure, the forming of experts, of measures 
with long term impact.

The principle based on which our country has registered progress in this area was "learning by doing", the practical transcription of some principles, rules and regulations, the system practically adjusting on the way.

The administration of the pre-adherence funds has determined also a training of the institutions of Romania's administration and an adjustment to the work manner characteristic to the EU: there has been a certain harshness through the following of strict regulations a more thorough work manner, the honoring of deadlines, honoring of demands regarding documents.

Insuring the continuous training of public workers (especially the ones in the administration sector ) for a correct and efficient administration of structural funds. As it is well known the learning process has started long before Romania's integration to the European Union through the organization of trainings by different institutions, especially by the NIA ${ }^{1}$. These classes were organized throughout PHARE funding.

If in the past the administration was faced with the migration of labour force due to the competition represented by the private sector, especially due to the more attractive salaries offered by them, at present, especially for the young sector the jobs offered by Brielle's represent a good opportunity regarding work places.

As a means to prevent this problem, at the suggestion of the European Commity, Romania has voted the law 490/2004 refering to the stimulation of the internal personnel working in the administration sector. even in these conditions it is appreciated that this mean is not sufficient.

The training of beneficiaries, meaning the growth of the information degree regarding the methods and means to access funds. There are informational campaigns organized locally and regionally for the open public as well as for the specialists.

The possibility to ensure the co-financing by participants. An important aspect which will affect the implementation of the projects regards the credit possibilities existent on the market for various potential beneficiaries. Insuring the internal financial resources will also be a problem. However, it is appreciated that the Romanian banking system is prepared with a diversified product portfolio intended to ensure credits for co-financing of structural funds.

\section{Inter - institutional communication.}

\section{Aspects that can lead to the diminish of the degree of absorption of communitary funds:}

- As part of the management component for community funds there is the problem if the structure of the internal scheme of the organizations involved in the administration of funds has been efficiently defined so as to ensure the growth of the absorption degree. Previous experiences in the pre-adherence funds administration have proven that the internal sector involved at an institutional level has been numerically inferior to the demand.

- The training for the administration of structural funds has been aggravated by the inexistence of a previous experiment that could have contributed to the forming of human resources. The only similar experience, but different in what procedures are involved, has been the accessing of pre-adherence funds.

- The occupational percentage at the end of the year 2006 has varied fro one management authority to another being between 28,3\% A M POS CCE and 67\% AM POS DRU.

- In chapter 21, The Government of Romania had committed itself to ensure the cofinancing of the expenses from the implementation of the cohesion policy. In this respect, there is the problem of finding solutions to ensure the public co-financing and to create the necessary conditions to attract foreign private investors. Although the co-financing effort from the state budget is a very important one, the majority of the pressure is on the local public authorities (the county and local councils) as main beneficiaries of two very important operational programmes: POR if POS for the Environment.

\footnotetext{
${ }^{1}$ The National Institute of Administration.
} 
- Another aspect that can lead to the diminishing of the degree of absorption is the fact that the beneficiaries have to have internal financial resources because the clearing with the Committee is done periodically based on justified documentation.

- The financing demands are grouped and sent to the Committee three times a year and another two months are needed for the committee to transfer the money. Therefore there can be a situation where a beneficiary whose statement of expenses had been certified at the beginning of January to be forced to wait until the end of June in order to receive his/hers payment.

\section{Conclusions}

We feel that it is needed a more accurate connection with the whole administrative system for the structural funds at the higher levels of decision from the Government. A regulate communication and debate at the level of ministers regarding the problems linked to the operational sector of the administrative structure for structural funds would be desirable in order to prioritize according to this process so as to ensure as much as possible a high level of absorption of community funds..

\section{References:}

1. Law number $215 / 2001$, regarding local public administration, republished.

2. Law number. 188/1999 regarding the status of public personnel, republished.

3. Law number. 7/2004 regarding The Conduct Code for public personnel, with the later modifications and anexes.

4. Law number. 315/2004 regarding regional development in Romania, with the later modifications and anexes.

5. H.G. number. 497/2004 regarding the establishing of the institutional frame for the coordonation, implementation and administration of the structural instruments with the later modifications and anexes.

6. The European Union - institutions, their role, the Economic and Social Cohesion Policy (the Regional Policy), The Common Agricultural Policy (www.europa.eu.int; www.infoeuropa.ro- sections „European Union”, „Publications and Resources”), www.mie.ro- section „Romania and EU”).

7. Regulation Number 1080/2006 of the European Parliament and the Council regarding The European Fund of Regional Development. (www.fonduri-structurale.ro)

8. Regulation Number 1081/2006 of the European Parliament and the Council regarding The European Social Fund (www.fonduri-structurale.ro)

9. Regulation Number 1083/2006 of the European Parliament and the Council regarding general foresites of the European Fund of Regional Development, the European Social Fund and the Cohesion Fund. (www.fonduri-structurale.ro)

10. The Strategic National Reference Environment 2007-2013. (www.inforegio.ro)

11. The Regional Operational Programme 2007-2013 (www.inforegio.ro)

12. The Frame Document for implementation of the cadru de implementare a Regional Operational Programme 2007-2013. (www.inforegio.ro) 